\title{
The Supreme Court, the Texas Abortion Law (SB8), and the Beginning of the End of Roe $v$ Wade?
}

\author{
I. Glenn Cohen \\ Petrie-Flom Center for Health Law Policy, Biotechnology, and Bioethics, Harvard Law School \\ Eli Y. Adashi \\ Medicine and Biological Sciences, Brown University \\ Lawrence O. Gostin \\ Georgetown University - Law Center - O'Neill Institute for National and Global Health Law, \\ gostin@law.georgetown.edu
}

This paper can be downloaded free of charge from:

https://scholarship.law.georgetown.edu/facpub/2413

https://ssrn.com/abstract=3944703

The Journal of the American Medical Association Health Forum, published online September 23, 2021, at E1-E2.

This open-access article is brought to you by the Georgetown Law Library. Posted with permission of the author. Follow this and additional works at: https://scholarship.law.georgetown.edu/facpub

Part of the Health Law and Policy Commons, and the Law and Gender Commons 


\section{The Supreme Court, SB8 and the Beginning of the End of Roe v. Wade?}

By

I. Glenn Cohen JD, Eli Y. Adashi MD and Lawrence O. Gostin JD

I. Glenn Cohen JD, Deputy Dean and James A. Attwood and Leslie Williams Professor of Law, Harvard Law School, Faculty Director, Petrie-Flom Center for Health Law Policy, Biotechnology, and Bioethics, Harvard University, Cambridge, MA.

Eli Y. Adashi MD, MS, Professor of Medical Science, Former Dean of Medicine and Biological Sciences, Brown University, Providence, RI.

Lawrence O. Gostin, JD, University Professor and Founding Faculty Director, O'Neill Institute for National and Global Health Law, Georgetown University Law Center, Washington, DC

Corresponding Author: I. Glenn Cohen Deputy Dean and James A. Attwood and Leslie Williams Professor of Law, Harvard Law School, Faculty Director, Petrie-Flom Center for Health Law Policy, Biotechnology, and Bioethics, Harvard University, 1525 Massachusetts Ave, Griswold Hall Room 503, Cambridge, MA 02138. igcohen@law.harvard.edu. Phone: 857-205-3068.

Financial Disclosures: Professors Cohen, Adashi, and Gostin declare no conflicts of interest.

Funding/Support: None

Word Count: 1223 
Thirteen states have enacted so-called "fetal heartbeat" laws banning abortions once embryotic cardiac activity can be detected. Courts have enjoined their enforcement as unconstitutional. However, on September 1, 2021, the Supreme Court declined to block a Texas fetal heartbeat law, which virtually eliminates access to abortion services.

Texas Governor Greg Abbott signed SB8 into law on May 19 ${ }^{\text {th }}$, with an effective date of September $1^{\text {st }}$. SB8 states, "a physician may not knowingly perform or induce an abortion on a pregnant woman if the physician detected a fetal heartbeat for the unborn child," absent a medical emergency, and requires physicians to search for cardiac activity before aborting the fetus. ${ }^{1}$ The law essentially prohibits abortion after 6 weeks of gestational age, before most women know they are pregnant.

Texas' fetal heartbeat law has a unique feature. It empowers private individuals to bring civil lawsuits not just against physicians but also against anyone who "knowingly engages in conduct that aids or abets the performance or inducement of an abortion," regardless of whether the person knew the abortion was unlawful. It includes "reimbursing the costs of an abortion through insurance." The language is so broad that it could cover a friend, clergyman, or even a driver who counsels a woman or transports her to an abortion clinic. SB8 goes further, imposing liability if the person even "intends to engage in the conduct." Any citizen may bring a civil lawsuit and, if successful, violators are required to pay damages of $\$ 10,000$ or more for each abortion, along with costs and attorney's fees. SB8 therefore leaves the law's enforcement not to state officials, but to private individuals, who are rewarded with damages. ${ }^{1}$

\section{The Law's Constitutionality}


Existing Supreme Court precedent, particularly Roe v. Wade and Planned Parenthood v. Casey, unambiguously prohibits states from outright bans on pre-viability abortions. The Texas legislation sought to evade judicial review by enforcing the law exclusively through private civil actions, while prohibiting state officers from enforcement. ${ }^{1}$ The seminal Supreme Court case of Ex Parte Young ${ }^{2}$ allows a federal court to enjoin an unconstitutional law by suing a state official administering the law. By prohibiting state enforcement, Texas sought to prevent constitutional challenges, effectively insulating the state from meaningful judicial review.

The law's goal is to deter physicians from offering abortions, and that has been the effect. Planned Parenthood reports that $85 \%$ to $90 \%$ of those who seek abortions in Texas are at least six weeks into pregnancy. ${ }^{3}$ Texas clinics are turning away women and some have discontinued providing abortion services. Many women will find it difficult to travel to another state for abortion services; the average trip has gone from 12 to 248 miles one-way. Lower-income women may lack the means to travel (e.g., time-off from work, childcare, transportation costs). ${ }^{4}$ Traveling long distances for an abortion might also alert a woman's domestic partner placing her at risk.

Texas abortion providers and abortion rights groups brought a lawsuit challenging the law's constitutionality naming various Texas officials and seeking an order to prevent the enforcement of the law during the pendency of the litigation. On September $1^{\text {st }}$, the U.S. Supreme Court allowed the Texas law to go into effect at least for now. An unsigned 5-4 opinion, the Court acknowledged "serious" constitutional questions, but said it "presents complex and novel" procedural questions and thus declined relief. ${ }^{5}$ The dissenting justices largely viewed Texas' attempt to circumvent constitutional review as a fig leaf, and would have the courts "consider whether a state can avoid responsibility for its laws." ${ }^{5}$ Justice Sotomayor, joined by Justices Kagan 
and Breyer, stated that the majority's order was "stunning," describing Texas law as "flagrantly unconstitutional," flouting 50 years of federal precedent. $^{5}$

\section{The Future of Constitutional Protection of Abortion Services}

Roe v. Wade and Planned Parenthood v. Casey have arguably taken on the status of "super-precedent," with parts of society heavily invested in their preservation. At her confirmation hearing, Justice Barrett refused to accord Roe this status, and it appears there may now be five votes for that view. To be sure, in the years since Roe, the Supreme Court has repeatedly cut back on the right to abortion, but never to the magnitude sought by Texas. This term, the Court will hear Dobbs v. Jackson Women's Health Organization, a challenge to the constitutionality of a Mississippi law that (with limited exceptions) bars abortions after the $15^{\text {th }}$ week of pregnancy. In that case, the Court may be poised to abandon Roe's core ruling that the state may not proscribe abortions before fetal viability. Mississippi's opening brief unabashedly states: "Roe and Casey are egregiously wrong. The conclusion that abortion is a constitutional

right has no basis in text, structure, history, or tradition." ${ }^{6}$ While the Court might uphold Mississippi's law without fully abandoning constitutional protection of abortion services, it is hard to see how it could do the same with Texas' law. If a state can constitutionally ban abortion at 6 weeks, there is effectively nothing left of the Court's constitutional protection of abortion.

The Supreme Court may still rule on the Texas case, it may even find it unconstitutional, but its decision to allow the law to go into effect means many will women will be unable to access abortion. As clinics close, abortion services will become difficult to obtain in the state. Public officials of any political party should be concerned, both morally and legally, by the idea that states can deputize citizens as the state's agents of enforcement and shield a law against 
constitutional review. If such a rule was adopted, there is nothing to stop states with very different political motivations from trying the same gambit - for example, to outlaw handgun ownership in violation with the Supreme Court's Second Amendment jurisprudence and avoid review by making it private citizens, and not the state, who enforce the law through civil actions. What happens next? On Sept $3^{\text {rd }}$, a district court issued a temporary restraining order to block enforcement of the law against certain abortion providers. But this order is only binding as to particular parties. The United States Department of Justice has brought its own suit naming the state of Texas as the defendant, and on Sept 14, 2021, sought a temporary restraining order or preliminary injunction against SB8. Its filing opens by intoning that Texas' "unprecedented scheme . . to shield a plainly unconstitutional law from review cannot stand." ${ }^{7}$ It argues that even if Texas' law prevents private individuals from bringing suit at this stage, "those obstacles do not impede ... an action by the United States against the State of Texas Itself." ${ }^{7}$ The district court has agreed to hold a hearing on this motion on Oct 1, 2021. Whether it grants or denies the motion, its ruling will enable appellate and ultimately Supreme Court review. Whether the Supreme Court takes this opportunity to revisit its earlier decision to let the Texas law stand remains to be seen.

Lawyers will continue to debate the intricacies of Ex Parte Young, stays, and sovereign immunity in this case. But this desiccated judicial wrangling must not distract from the reality facing physicians on the front line of providing abortions, and for low-income women in their care: abortions have become largely unavailable in Texas. This is a profoundly disturbing reality, but one the U.S. Supreme Court has thus far allowed to persist. 


\section{References}

1. SB 8, Tex. (2021), available at https://legiscan.com/TX/text/SB8/2021

2. 209 U.S. $123(1908)$

3. Planned Parenthood of Greater Texas Surgical Health Services v. Texas Right to Life, Plaintiffs' Original Petition and Request for Declaratory Judgment and Application for Temporary Restraining Order and/or Anti-Suit Injunction, 2021 WL 4079311 (Tex. Dist.

Sept. 2, 2021) (https://www.scribd.com/document/523016915/Planned-Parenthood-vsTexas-Right-to-Life-temporary-restraining-order-request\#from embed )

4. Most Extreme Abortion Law in US Takes Effect in Texas. The Guardian. September 2, 2021. (https://www.theguardian.com/us-news/2021/sep/01/texas-abortion-lawsupreme-court)

5. Whole Women's Health v. Jackson, 594 U.S. _ (2021).

6. Dobbs v. Jackson Women's Health, No 19-1392, Brief for Petitioners (https://www.washingtonpost.com/context/mississippi-s-supreme-court-brief-dobbs-vjackson-women-s-health-organization/d59fcfd4-b8ec-42a8-b8e1-e54755fbd4f6/)

7. United States v. Texas, United States' Emergency Motion for a Temporary Restraining Order or Preliminary Injunction, Case No. 1:21-cv-796-RP (W.D. Tex. Sept 14, 2021) (https://s3.documentcloud.org/documents/21062495/9-14-21-us-motion-for-tro-pitexas-sb8.pdf ) 